\title{
PENERAPAN METODE PEMBELAJARAN KONVENSIONAL TERHADAP HASIL BELAJAR FISIKA PESERTA DIDIK
}

\section{THE IMPLEMENTATION OF THE CONVENTIONAL LEARNING METHOD TO PHYSICS LEARNING OUTCOMES OF STUDENTS}

\author{
Andi Ferawati Jafar \\ Fakultas Tarbiyah dan Keguruan Universitas Islam Negeri Alauddin Makassar \\ feemakassar@yahoo.com
}

\begin{abstract}
Abstrak
Penelitian ini bertujuan untuk mengetahui hasil belajar peserta didik dengan menggunakan metode konvensional pada materi suhu dan kalor peserta didik kelas VII B MTs Negeri 3 Enrekang. Adapun metode penelitian yang digunakan yaitu quasi eksperimen dengan One Group Pre and Post Test. Sampel penelitian ini adalah kelas VII B sebanyak 24 orang. Pengumpulan data dilakukan dengan menggunakan tes hasil belajar. Teknik analisis data menggunakan analisis statistik deskriptif dan analisis statistik inferensial. Berdasarkan hasil analisis statistik deskriptif, nilai rata-rata pre test hasil belajar peserta didik yaitu 49,83, sedangkan nilai rata-rata post test hasil belajar peserta didik, yaitu 57,58. Selanjutnya, berdasarkan uji hipotesis diperoleh bahwa tidak terdapat perbedaan hasil belajar yang signifikan antara hasil belajar peserta didik sebelum menerapkan metode pembelajaran konvensional dengan hasil belajar peserta didik setelah menerapkan metode konvensional. Implikasi penelitian ini yaitu diharapkan agar pendidik dapat berinovasi dalam memilih metode mempelajaran dan menyesuaikan dengan materi yang akan diajarkan, agar nilai hasil belajar peserta didik dapat meningkat secara signifikan.
\end{abstract}

Kata Kunci: metode konvensional, hasil belajar

\begin{abstract}
This study aims to determine student learning outcomes using conventional methods on the material of temperature and heat for class VII B students of MTs Negeri 3 Enrekang. The research method used is quasi-experimental with One Group Pre and Post Test. The sample of this research is class VII B as many as 24 people. Data collection is done by using the learning outcomes test. The data analysis technique used descriptive statistical analysis and inferential statistical analysis. Based on the results of descriptive statistical analysis, the average value of the pre-test of student learning outcomes is 49.83, while the average value of the post-test of student learning outcomes is 57.58. Furthermore, based on hypothesis testing, it was obtained that there was no significant difference in learning outcomes between student learning outcomes before applying conventional learning methods and student learning outcomes after applying conventional methods. The implication of this research is that it is hoped that educators can innovate in choosing learning methods and adapting to the material to be taught, so that the value of student learning outcomes can increase significantly.
\end{abstract}

Keywords: conventional method, learning outcomes

How to Cite: Jafar, A. F. (2021). Penerapan metode pembelajaran konvensional terhadap hasil belajar fisika peserta didik. Al asma: Journal of Islamic Education, 3(2), 190-199. 


\section{PENDAHULUAN}

Salah satu tujuan pembelajaran fisika di sekolah adalah agar peserta didik memiliki kemampuan menguasai konsep dan prinsip fisika serta mempunyai keterampilan mengembangkan pengetahuan dan sikap percaya diri sebagai bekal untuk melanjutkan pendidikan pada jenjang yang lebih tinggi serta mengembangkan ilmu pengetahuan dan teknologi (Depdiknas: 2006). Tuntutan kurikulum 2013 melalui mata pelajaran fisika, diharapkan dapat menumbuhkan kemampuan berpikir peserta didik yang berguna untuk memecahkan masalah dalam kehidupan sehari-hari.

Menurut UU Nomor 20 tahun 2003 tentang Sisdiknas, pembelajaran adalah proses interaksi peserta didik dengan pendidik dan sumber belajar pada 4 suatu lingkungan belajar. Sesuai dengan materi pelajaran fisika adalah alam beserta isinya, antara lain berupa fenomena alam yang meliputi penyebab, proses, dan dampaknya/penerapannya, maka sumber belajar fisika adalah lingkungan alam di sekitar peserta didik. Karakteristik fisika yang meliputi proses dan produk juga perlu dipertimbangkan dalam pembelajaran fisika.

Fisika adalah bagian dari ilmu pengetahuan alam yang dalam pelaksanaan pembelajarannya diperlukan banyak keterampilan mendasar, yaitu mengamati, menghitung, mengukur, mengklasifikasi, dan berpresentasi. Hal tersebut bertujuan meningkatkan keterampilan mendasar peserta didik untuk dapat memahami proses penemuan suatu konsep. Namun kebanyakan dari pembelajaran fisika hanya menekankan pada aspek penguasaan konsep, sehingga menyebabkan peserta didik menjadi pasif dan kurangnya pelaksanaan latihan keterampilan.

Dalam menunjang keberhasilan pembelajaran, guru harus menggunakan metode pembelajaran yang baik dan sesuai dengan materi. Guru yang baik haruslah mengetahui metode-metode pembelajaran yang cocok dengan materi yang akan diajarkan, jangan sampai metode yang digunakan tidak cocok yang bisa membuat para peserta didik kurang memahami inti dari materi yang sedang diajarkan dan akan membuat hasil belajar peserta didik menurun atau tidak sesuai dengan kriteria kelulusan.

Metode adalah rencana menyeluruh penyajian (pengajaran/pembelajaran) secara sistematis berdasarkan pendekatan yang ditentukan. Metode mengajar adalah ilmu yang mempelajari cara-cara untuk melakukan aktivitas yang tersistem dari sebuah lingkungan yang terdiri dari pendidik dan peserta didik untuk saling berinteraksi dalam melakukan suatu kegiatan sehingga proses belajar berjalan dengan baik dalam arti tujuan pengajaran tercapai. Media pengajaran adalah alat, metode dan teknik yang digunakan dalam rangka lebih mengefektifkan komunikasi dan interaksi antara guru dan siswa dalam proses pendidikan dan pengajaran di sekolah (Hamalik, 1994:12). Metode konvensional (ceramah) merupakan sebuah bentuk interaksi melalui penerangan dan penuturan secara lisan oleh seorang guru terhadap siswa di kelasnya (Mansyur, 1991:138-139).

Metode ceramah, metode ini tergolong metode konvensional karena persiapannya paling sederhana dan mudah, fleksibel tanpa memerlukan persiapan khusus. Menurut (Sriyono, 1992:99), metode ceramah adalah penuturan dan penjelasan guru secara lisan. Dimana dalam pelaksanaannya guru dapat menggunakan alat bantu mengajar untuk memperjelas uraian yang disampaikan kepada peserta didik. Metode pengajaran yang dilaksanakan dalam penelitian ini yaitu metode konvensional (ceramah). Penggunaan metode mengajar yang kurang tepat akan mengakibatkan dampak yang kurang optimal terhadap hasil belajar siswanya. Proses pembelajaran yang tidak efektif merupakan faktor 
penyebab rendahnya hasil belajar sehingga peneliti tertarik untuk menggunakan metode animasi untuk mengoptimalkan hasil belajar siswa. Banyak pengertian belajar yang dapat dipakai untuk menjelaskan definisi belajar.

Hasil belajar dapat diuraikan dari segi bahasa. Pengertian ini terdiri dari 2 kata "hasil" dan "belajar". Dalam KBBI hasil memiliki beberapa arti: 1. Sesuatu yang diadakan (dibuat, dijadikan, dan sebagainya) oleh usaha, 2. Pendapatan; perolehan; buah, 3. Berhasil; mendapatkan hasil; tidak gagal, sedangkan belajar menurut KBBI artinya: 1. Berusaha memperoleh kepandaian kepada orang supaya diketahui (diturut), 2. Berlatih, 3. Berubah tingkah laku atau tanggapan yang disebabkan oleh pengalaman. (Badan Pembinaan dan Pengembangan Bahasa, Kemdikbud, Kampus Besar Bahasa Indonesia (KBBI) (Ichnatun, Qaddafi, \& Jafar, 2019: 178-179)

Hasil belajar menurut Grolund adalah suatu hasil yang diharapkan dari pembelajaran yang telah ditetapkan dalam rumusan perilaku tertentu. Menurut Sudijarto (1993), hasil belajar adalah tingkat pernyataan yang dicapai oleh siswa dalam mengikuti program pembelajaran sesuai dengan tujuan pendidikan yang ditetapkan. Menurut A.J. Romiszowski hasil belajar merupakan keluaran (output) dari suatu sistem pemrosesan masukan (input) (Abdurrahman, 2012:26).

Menurut Benjamin S. Bloom ada tiga ranah (domain) hasil belajar, yaitu kognitif, afektif, dan psikomotorik". Domain kognitif adalah knowledge (pengetahuan, ingatan), comprehension (pemahaman, menjelaskan, meringkas, contoh), application (menerapkan), analysis (menguraikan, menentukan hubungan), synthesis (mengorganisasikan, merencanakan, membentuk bangunan baru), dan evaluation (menilai). Domain efektif adalah receiving (sikap menerima), responding (memberikan respons), valuing (nilai), organization (organisasi), characterization (karakterisasi). Domain psikomotor meliputi initiatory, preroutine, dan routinized. Psikomotor juga mencakup keterampilan produktif, teknik, fisik, sosial, manajerial, dan intelektual. Sementara, menurut Lindgren hasil pembelajaran meliputi kecakapan, informasi, pengertian, dan sikap (Suprijono, 2013:6-7). Benyamin Bloom mengklasifikasikan hasil belajar secara garis besar menjadi tiga ranah, ranah kognitif (intelektual) yang terdiri atas enam aspek, yakni pengetahuan atau ingatan, pemahaman, aplikasi, analisis, sintesis, dan evaluasi (Hidayat \& Andira, 2019:145). Hasil belajar pencapaian bentuk perubahan perilaku yang cenderung menetap dari ranah kognitif, afektif, dan psikomotoris dari proses belajar yang dilakukan dalam waktu tertentu (Jihad \& Haris, 2012: 14).

Berdasarkan hasil observasi peneliti di lapangan, pembelajaran fisika dilakukan dengan metode pembelajaran konvensional yaitu dengan ceramah, dengan rata-rata hasil belajar peserta didik berada di atas Kriteria Ketuntasan Minimal (KKM). Penelitian terdahulu yang dilakukan oleh Zaini \& Marsigit (2014) dan Ruhulessin, Ratumanan, \& Tamalene (2019) tentang pembelajaran dengan pendekatan konvensional menyatakan bahwa pembelajaran dengan pendekatan konvensional tidak efektif terhadap hasil belajar peserta didik. Hal tersebut menunjukkan bahwa hasil penelitian terdahulu bertolak belakang dengan fakta yang ditemukan peneliti di lapangan pada observasi yang telah dilakukan sehingga peneliti tertarik untuk melakukan penelitian dengan judul "Pengaruh Penerapan Metode Pembelajaran Konvensional terhadap Hasil Belajar Peserta Didik". Tujuan pada penelitian ini yaitu untuk mengetahui gambaran hasil belajar fisika peserta didik yang diajar menggunakan metode konvensional dan untuk mengetahui adakah 
perbedaan hasil belajar antara hasil belajar peserta didik sebelum menerapkan metode pembelajaran konvensional dengan hasil belajar peserta didik setelah menerapkan metode konvensional.

\section{METODE PENELITIAN}

Metode penelitian yang penulis gunakan dalam penelitian ini adalah metode penelitian eksperimen. Desain penelitian pada penelitian ini adalah penelitian kuantitatif dengan menggunakan metode pre-experimental design tipe one group pretest-posttest (tes awal-tes akhir kelompok tunggal).

Rancangan one group pretest-posttest design ini terdiri atas satu kelompok yang telah ditentukan. Di dalam rancangan ini dilakukan tes sebanyak dua kali, yaitu sebelum diberi perlakuan disebut prates dan sesudah perlakuan disebut pas-cates. Adapun pola penelitian metode one group pretest-posttest design menurut (Sugiyono, 2016) Sugiyono (2016:75) sebagai berikut:

$$
\mathrm{O}_{1} \mathrm{XO}_{2}
$$

01 : nilai pre test (sebelum perlakuan)

$\mathrm{X} \quad$ : metode pembelajaran konvensional (ceramah)

02 : nilai post test (setelah diberi perlakuan)

Populasi dalam penelitian ini adalah seluruh siswa kelas VII MTs Negeri 3 Enrekang yang terdiri dari 6 kelas yaitu VII A - VII F dimana jumlah keseluruhan siswa kelas VII MTs Negeri 3 Enrekang sebanyak 147 peserta didik . Adapun sampel pada penelitian ini yaitu kelas VII B MTs Negeri 3 Enrekang sebanyak 24 peserta didik.

Instrumen penelitian yang digunakan oleh peneliti untuk mengumpulkan data adalah tes hasil belajar, lembar observasi, dan RPP. Data yang diperoleh dalam penelitian ini berupa data kuantitatif, kemudian dengan membandingkan nilai rata-rata hasil belajar pre test dan post test peseta didik. Teknik analisis data yang relevan dalam penelitian ini adalah metode analisis kuantitatif menggunakan statistik deskriptif dan inferensial. Yang termasuk dalam teknik statistik deskriptif yaitu membuat tabel distribusi frekuensi, nilai rata-rata, standar deviasi, dan variansi (Sudjana, 1992:93).

Analisis statistik inferensial terdiri dari uji normalitas dan pengujian hipotesis. Uji normalitas dilakukan dengan menggunakan aplikasi IBM SPSS tic versi 20 for Windows dengan analisis Kolmogrov-Smirnov pada taraf signifikansi $\alpha=0,05$. dengan kategori pengujian jika nilai sig. $\geq 0,05 ; \mathrm{H}_{0}$ diterima, sehingga dapat disimpulkan bahwa sampel berasal dari populasi yang berdistribusi normal dan jika nilai sig. $<0,05 ; \mathrm{H}_{0}$ ditolak, sehingga dapat disimpulkan bahwa sampel berasal dari populasi yang tidak terdistribusi normal. Untuk pengujian hipotesis pada penelitian ini menggunakan uji-t 1 sampel berpasangan parametris pada taraf signifikan $\alpha=0.05$. Hipotesis statistik $H_{0}: \mu 1=\mu 2$ dan $H_{1}: \mu 1 \neq \mu 2$ $\left(\mathrm{H}_{0}\right.$ : Tidak terdapat perbedaan rata-rata nilai hasil belajar fisika peserta didik sebelum dan setelah diajar menggunakan metode konvensional dan $\mathrm{H}_{1}$ : Terdapat perbedaan rata-rata nilai hasil belajar fisika peserta didik sebelum dan setelah diajar menggunakan metode 
konvensional). Penarikan kesimpulan Jika nilai $t_{\text {hitung }}>t_{\text {tabel}}$, maka hipotesis diterima dan jika nilai $t_{\text {hitung }}<t_{\text {tabel, }}$ maka hipotesis ditolak (Sugiyono, 2016:303-304).

\section{HASIL DAN PEMBAHASAN}

1. Analisis Deskriptif Hasil Belajar Pre Test Peserta Didik

Berdasarkan hasil penelitian yang telah dilakukan di kelas Kelas VII B MTs Negeri 3 Enrekang, penulis mengumpulkan data melalui soal-soal tes hasil belajar dan diolah dengan analisis statistik deskriptif dengan menggunakan program SPSS v.20 sebagai berikut:

Tabel 1. Hasil Analisis Deskriptif Skor Hasil Belajar Pre Test Peserta Didik Kelas VII B dengan SPSS

\begin{tabular}{lr}
\hline \multicolumn{2}{c}{ Statistics } \\
\hline \multirow{2}{*}{$N$ Valid } & 24 \\
\cline { 2 - 2 } Missing & 0 \\
\hline Mean & 49,5833 \\
\hline Median & 50,0000 \\
\hline Std. Deviation & 10,82636 \\
\hline Variance & 117,210 \\
\hline Range & 40,00 \\
\hline Minimum & 30,00 \\
\hline Maximum & 70,00 \\
\hline
\end{tabular}

Berdasarkan hasil analisis deskriptif SPSS v.20 pada tabel 1 tersebut, dapat disimpulkan bahwa nilai maksimum atau nilai paling tinggi yang diperoleh peserta didik adalah 70. Sedangkan nilai minimum atau nilai paling rendah yang diperoleh peserta didik adalah 30. Adapun nilai rata-rata yang diperoleh adalah sebesar 49,58 dengan standar deviasi sebesar 10,83. Dengan demikian, diperoleh varians sebesar 117,21.

Berdasarkan hasil analisis deskriptif yang diperoleh, maka hasil belajar peserta didik dikategorisasi berdasarkan dari nilai yang diperoleh dapat ditunjukkan sebagai berikut:

Tabel 2. Kategorisasi Hasil Belajar Pre Test Peserta Didik Kelas VII B

\begin{tabular}{cccc}
\hline Rentang Skor & Frekuensi & Persentase & Kategorisasi \\
\hline $0-37,50$ & 0 & $0 \%$ & Sangat Rendah \\
\hline $37,75-54,25$ & 17 & $78,83 \%$ & Rendah \\
\hline $54,50-71,00$ & 7 & $21,17 \%$ & Sedang \\
\hline $71,25-87,50$ & 0 & $0 \%$ & Tinggi \\
\hline $87,75-100$ & 0 & $0 \%$ & Sangat Tinggi \\
\hline Jumlah & $\mathbf{2 4}$ & $\mathbf{1 0 0} \%$ & \\
\hline
\end{tabular}

Berdasarkan tabel 2, dapat diperoleh sebaran nilai hasil belajar pre test peserta didik berdasarkan kategori distribusi frekuensi. Terdapat 17 peserta didik pada kategori rendah dengan persentase $78,83 \%$, dan 7 orang peserta didik pada kategori sedang dengan persentase $21,17 \%$, dari jumlah total peserta didik sebanyak 24 orang. 


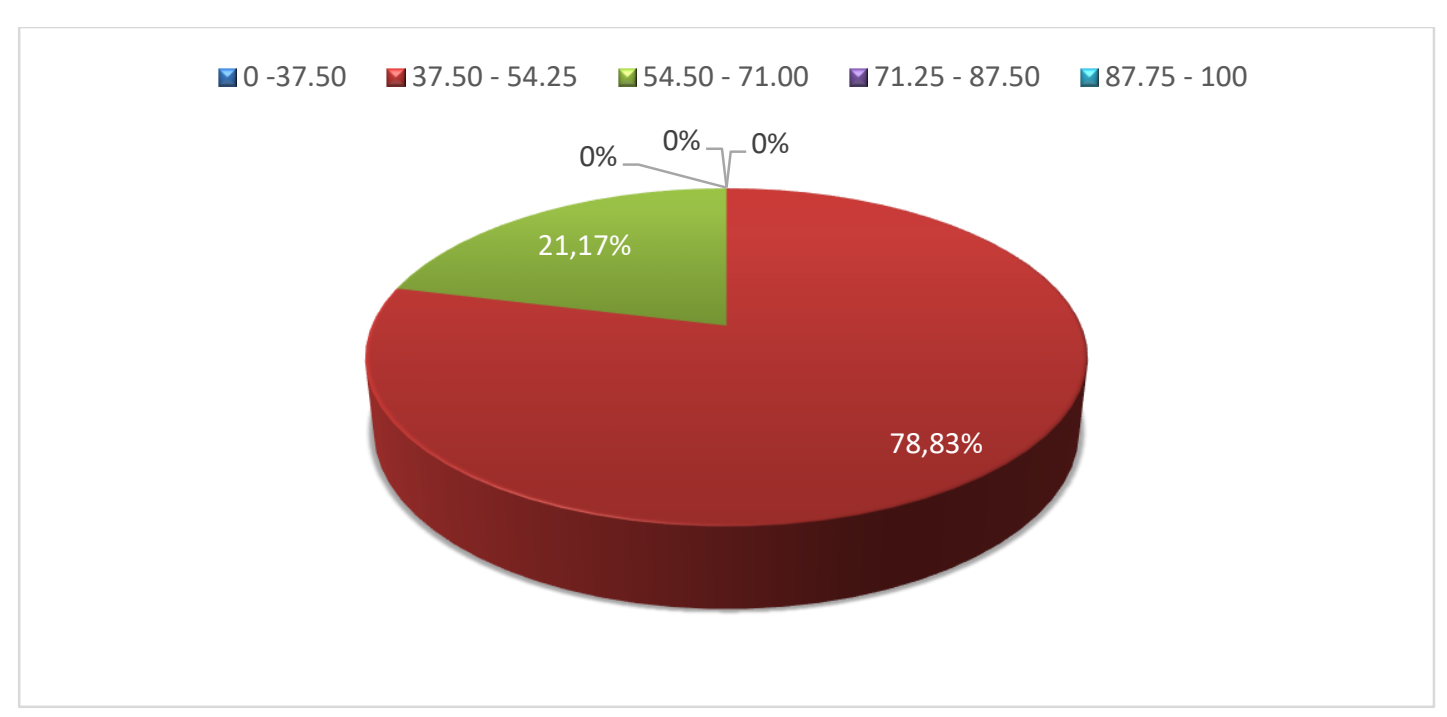

Gambar 1. Diagram Kategorisasi Hasil Belajar Pre Test Peserta Didik Kelas Kontrol

Berdasarkan gambar 1, dapat ditunjukkan kategorisasi nilai hasil belajar kelas kontrol yakni terdapat 17 orang peserta didik pada rentang nilai 37,75-54,25 dengan persentase $78,83 \%$, dan 7 orang peserta didik pada rentang nilai 54,50-71,00 dengan persentase $21,17 \%$ dari 24 jumlah peserta didik.

Pada bagian ini diuraikan hasil penelitian yang diperoleh, dapat disajikan dalam bentuk grafik, tabel, ataupun gambar, dan disertai dengan narasi pembahasan yang bersesuaian dengan hasil tersebut. Pembahasan hasil penelitian didukung oleh rujukan dan penelitian pendukung yang sesuai dengan hasil penelitian.

\section{Analisis Deskriptif Hasil Belajar Post Test Kelas VII B}

Berdasarkan hasil penelitian yang telah dilakukan di kelas Kelas VII B MTs Negeri 3 Enrekang, penulis mengumpulkan data melalui soal-soal tes hasil belajar dan diolah dengan analisis statistik deskriptif dengan menggunakan program SPSS v.20 sebagai berikut:

Tabel 3. Hasil Analisis Deskriptif Skor Hasil Belajar Post Test Peserta Didik Kelas VII B dengan SPSS

\begin{tabular}{|c|c|}
\hline \multicolumn{2}{|c|}{ Statistics } \\
\hline Valid & 24 \\
\hline Missing & 0 \\
\hline Mean & 57,5833 \\
\hline Median & 57,0000 \\
\hline Std. Deviation & 8,97783 \\
\hline Variance & 80,601 \\
\hline Range & 35,00 \\
\hline Minimum & 43,00 \\
\hline Maximum & 78,00 \\
\hline
\end{tabular}

Berdasarkan hasil analisis deskriptif SPSS v.20 pada tabel 3 tersebut, dapat disimpulkan bahwa nilai maksimum atau nilai paling tinggi yang diperoleh peserta didik adalah 78. Sedangkan nilai minimum atau nilai paling rendah yang diperoleh peserta didik 
adalah 43. Adapun nilai rata-rata yang diperoleh adalah sebesar 57,58 dengan standar deviasi sebesar 8,97783. Dengan demikian, diperoleh varians sebesar 80,601.

Berdasarkan hasil analisis deskriptif yang diperoleh, maka hasil belajar peserta didik dikategorisasi berdasarkan dari nilai yang diperoleh dapat ditunjukkan sebagai berikut:

Tabel 4. Kategorisasi Hasil Belajar Post Test Peserta Didik Kelas VII B

\begin{tabular}{cccc}
\hline Rentang Skor & Frekuensi & Persentase & Kategorisasi \\
\hline $0-37,50$ & 0 & $0 \%$ & Sangat Rendah \\
\hline $37,75-54,25$ & 9 & $37,5 \%$ & Rendah \\
\hline $54,50-71,00$ & 14 & $58,3 \%$ & Sedang \\
\hline $71,25-87,50$ & 1 & $4,17 \%$ & Tinggi \\
\hline $87,75-100$ & 0 & $0 \%$ & Sangat Tinggi \\
\hline Jumlah & $\mathbf{2 4}$ & $\mathbf{1 0 0} \%$ & \\
\hline
\end{tabular}

Berdasarkan tabel 4, dapat diperoleh sebaran nilai hasil belajar peserta didik kelas kontrol berdasarkan kategori distribusi frekuensi. Terdapat 9 orang peserta didik pada kategori rendah dengan persentase 37,5\%, 14 orang peserta didik pada kategori sedang dengan persentase 58,3\%, dan 1 orang peserta didik pada kategori tinggi dengan persentase $4,17 \%$ dari jumlah total peserta didik sebanyak 24 orang.

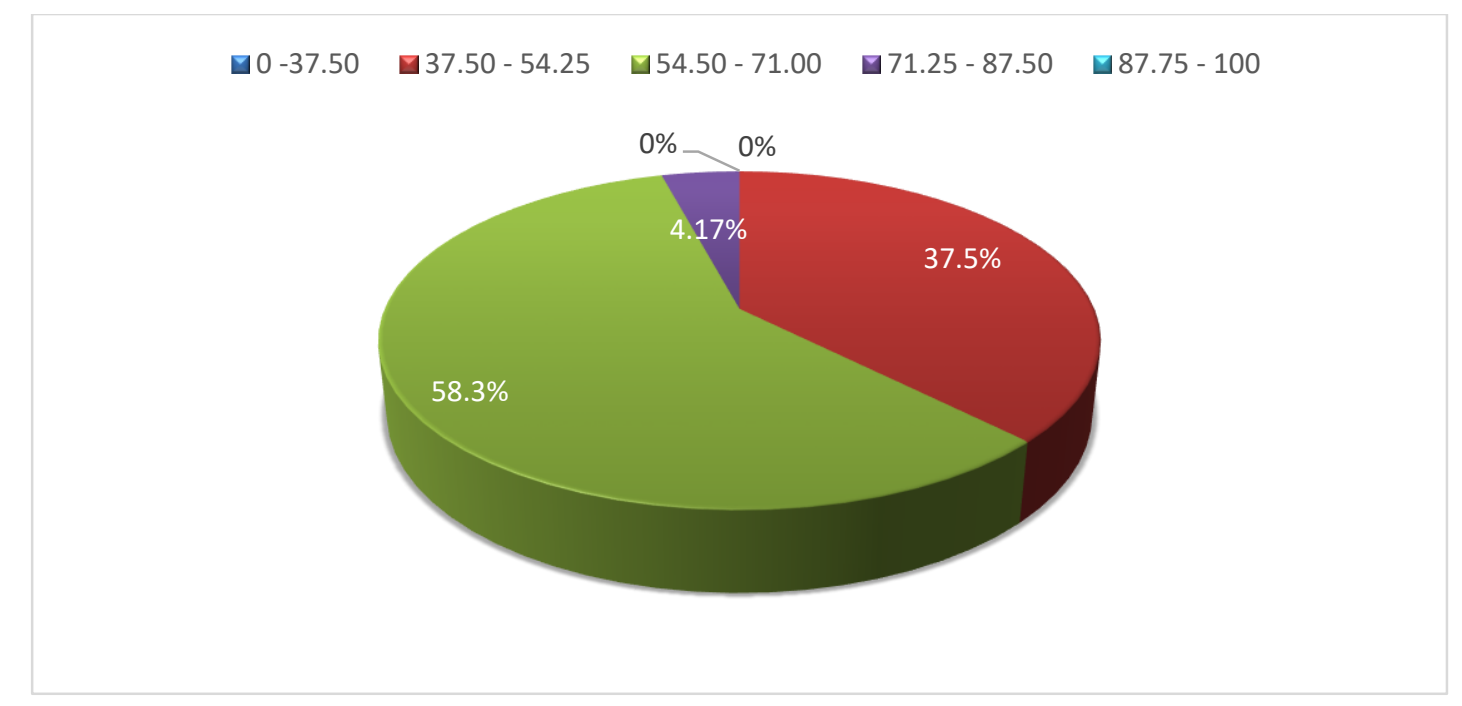

Gambar 2. Diagram Kategorisasi Hasil Belajar Post Test Peserta Didik Kelas VII B

Berdasarkan gambar 2, dapat ditunjukkan kategorisasi nilai hasil belajar yakni terdapat 9 orang peserta didik pada rentang nilai 37,75-54,25 dengan persentase 38\%, 14 orang peserta didik pada rentang nilai 54,50-71,00 dengan persentase $58 \%, 1$ orang peserta didik pada rentang nilai 71,25-87,50 dengan persentase 4\% dari 24 jumlah peserta didik.

Pada bagian ini diuraikan hasil penelitian yang diperoleh, dapat disajikan dalam bentuk grafik, tabel, ataupun gambar, dan disertai dengan narasi pembahasan yang bersesuaian dengan hasil tersebut. Pembahasan hasil penelitian didukung oleh rujukan dan penelitian pendukung yang sesuai dengan hasil penelitian. 
Berdasarkan uraian diatas, bahwa rata-rata hasil belajar post test dan pre test peserta didik yaitu sama berada pada kategori rendah, sehingga menunjukkan bahwa metode (ceramah) kurang berpengaruh terhadap hasil belajar peserta didik berdasarkan instrumen tes hasil belajar yang diberikan.

3. Uji Normalitas Nilai Pre Test

Adapun hasil perhitungan uji normalitas data nilai hasil belajar peserta didik setelah diolah dengan SPSS IBM v.20 ditunjukkan pada tabel 5.

Tabel 5. Uji Normalitas Nilai Pre Test kelas VII B

\begin{tabular}{|l|r|r|r|r|r|c|}
\hline \multicolumn{8}{|c|}{ Tests of Normality } \\
\hline & \multicolumn{3}{|c|}{ Kolmogorov-Smirnov ${ }^{a}$} & \multicolumn{3}{c|}{ Shapiro-Wilk } \\
\cline { 2 - 8 } & Statistic & Df & \multicolumn{1}{|c|}{ Sig. } & Statistic & Df & Sig. \\
\hline Pre Test & .154 & 24 & .200 & .914 & 24 & .065 \\
\hline
\end{tabular}

Berdasarkan tabel 5 tersebut, pada kolom Kolmogorov-Smimov diperoleh nilai signifikan sebesar 0,2. Nilai sig. ini lebih besar dari 0,05 (sig. > 0,05) sehingga disimpulkan bahwa nilai hasil belajar peserta didik pada pre test berdistribusi normal.

4. Uji Normalitas Nilai Post Test

Hasil uji normalitas data hasil belajar peserta didik setelah diolah dengan IBM SPSS v.20 ditunjukkan pada tabel 6 .

Tabel 6. Uji Normalitas Post Test kelas VII B

\begin{tabular}{|l|r|r|r|r|r|r|}
\hline \multicolumn{8}{|c|}{ Tests of Normality } \\
\hline & \multicolumn{3}{|c|}{ Kolmogorov-Smirnov ${ }^{a}$} & \multicolumn{3}{c|}{ Shapiro-Wilk } \\
\cline { 2 - 8 } & Statistic & \multicolumn{1}{|c|}{ Df } & \multicolumn{1}{c|}{ Sig. } & Statistic & \multicolumn{1}{c|}{ Df } & \multicolumn{1}{c|}{ Sig. } \\
\hline Post Test & .175 & 24 & .093 & .926 & 24 & .115 \\
\hline
\end{tabular}

Berdasarkan tabel 6 tersebut, pada kolom Kolmogorov-Smimov diperoleh nilai signifikan sebesar 0,093. Nilai sig. ini lebih besar dari 0,05 (sig. $>0,05$ ) sehingga disimpulkan bahwa nilai hasil belajar peserta didik post test berdistribusi normal.

\section{Uji Hipotesis}

Uji hipotesis yang digunakan dalam penelitian ini adalah uji t-1 sampel. Uji t-1 sampel digunakan karena sampel yang digunakan pada penelitian ini hanya 1 kelas. Berikut hasil perhitungan Uji t-1 sampel menggunakan program IBM SPSS v.20:

Tabel 7. Hasil Perhitungan Uji t-1 sampel

\begin{tabular}{|c|c|c|c|c|c|c|}
\hline \multicolumn{7}{|c|}{ One-Sample Test } \\
\hline & \multirow[t]{2}{*}{$T$} & \multirow[t]{2}{*}{$D f$} & \multirow[t]{2}{*}{$\begin{array}{l}\text { Sig. (2- } \\
\text { tailed) }\end{array}$} & \multirow[t]{2}{*}{$\begin{array}{l}\text { Mean } \\
\text { Difference }\end{array}$} & $\begin{array}{r}95 \% \mathrm{Co} \\
\mathrm{tl}\end{array}$ & $\begin{array}{l}\text { nce Interval of } \\
\text { fference }\end{array}$ \\
\hline & & & & & Lower & Upper \\
\hline Hasil Belajar & -9.504 & 23 & .000 & -17.41667 & -21.2077 & -13.6257 \\
\hline
\end{tabular}


Berdasarkan tabel 7, diperoleh nilai t hitung -9,504 dengan derajat kebebasan (DF) sebesar 23. Jika dibandingkan dengan nilai $\mathrm{T}$ tabel pada taraf signifikan 0,05 , yaitu $t_{\text {tabel }}=$ 1,714 , maka dapat disimpulkan bahwa $t_{\text {tabel }}>t_{\text {hitung }}(1,714>-9,504)$, sehingga $\mathrm{H}_{0}$ diterima dan $\mathrm{H}_{1}$ ditolak.

Berdasarkan uraian di atas, menunjukkan bahwa tidak terdapat perbedaan hasil belajar yang signifikan antara hasil belajar peserta didik sebelum menerapkan metode pembelajaran konvensional dengan hasil belajar peserta didik setelah menerapkan metode konvensional.

Berdasarkan kriteria ketuntasan yang telah ditetapkan dan hasil uji one sample $t$ test, maka pembelajaran konvensional tidak efektif terhadap hasil belajar. Berdasarkan observasi peneliti terhadap respon peserta didik, dilihat dari kegiatan pembelajaran yang berlangsung di kelas peserta didik kesulitan dalam memahami atau mengingat berbagai rumus, serta sangat kurangnya semangat peserta didik saat proses pembelajaran. Peserta didik hanya duduk dan mendengarkan apa yang dijelaskan oleh penelitidan tidak ada yang bertanya pada peneliti selama proses pembelajaran berlangsung, sangat jarang ada peserta didik yang secara suka rela maju kedepan ketika disuruh peneliti untuk menyelesaikan soal di papan tulis. Hal ini yang menyebabkan hasil belajar peserta didik tidak mencapai KKM. Hal ini sesuai dengan penelitian terdahulu yang dilakukan oleh Zaini \& Marsigit (2014) dengan hasil penelitian menunjukan bahwa 1) pembelajaran dengan pendekatan matematika realistik tidak efektif ditinjau dari kemampuan penalaran tetapi efektif ditinjau dari kemampuan komunikasi matematika; 2) pembelajaran matematika dengan pendekatan konvensional tidak efektif ditinjau dari kemampuan penalaran dan komunikasi matematik siswa; dan 3) pembelajaran pendekatan matematika realistik lebih baik dari pembelajaran konvensional ditinjau dari kemampuan penalaran dan komunikasi matematik siswa. Penelitian oleh Ruhulessin, Ratumanan, \& Tamalene (2019) dengan hasil penelitian bahwa hasil belajar siswa yang menggunakan model pembelajaran kooperatif tipe Student Facilitator and Explaining lebih baik bila dibandingan dengan yang menggunakan model pembelajaran konvensional.

\section{SIMPULAN}

Hasil belajar fisika peserta didik yang diajar menggunakan metode konvensional pada kelas VII B MTs Negeri 3 Enrekang memiliki nilai rata-rata 57,58. Hal ini menunjukkan bahwa rata-rata hasil belajar peserta didik berapa pada kategori rendah. Berdasarkan uji hipotesis menunjukkan bahwa tidak terdapat perbedaan hasil belajar yang signifikan antara hasil belajar peserta didik sebelum menerapkan metode pembelajaran konvensional dengan hasil belajar peserta didik setelah menerapkan metode konvensional. Implikasi penelitian ini yaitu diharapkan agar pendidik dapat berinovasi dalam memilih metode mempelajaran dan menyesuaikan dengan materi yang akan diajarkan, agar nilai hasil belajar peserta didik dapat meningkat secara signifikan.

\section{DAFTAR PUSTAKA}

Abdurrahman, M. (2012). Anak Berkesulitan Belajar: Teori, Diagnosis, dan Remediasinya. Jakarta: Rineka Cipta.

Hamalik, O. (1994). Media Pendidikan. Bandung: PT. Citra Aditya Bakti. 
Hidayat, M. Y., \& Andira, A. (2019). Pengaruh Media Pembelajaran Hybrid Learning berbantuan Media Schoology terhadap Hasil Belajar. JPF (Jurnal Pendidikan Fisika), 7(2), 140-148. https://doi.org/10.24252/jpf.v7i2.9442

Ichnatun, L., Qaddafi, M., \& Jafar, A. F. (2019). Penerapan Model Pembelajaran Blended Learning Manajemen System Edmodo terhadap Hasil Belajar. JPF (Jurnal Pendidikan Fisika), 7(2), 179-183.

Jihad, A., \& Haris, A. (2012). Evaluasi Pembelajaran. Yogyakarta: Multi Pressindo.

Mansyur. (1991). Strategi Belajar Mengajar. Jakarta: Universitas Terbuka.

Ruhulessin, S., Ratumanan, T. G., \& Tamalene, H. (2019). Perbedaan Hasil Belajar Siswa Kelas X SMA Menggunakan Model Pembelajaran Kooperatif Tipe Student Facilitator and Explaining (SFE) dan Model Pembelajaran Konvensional pada Materi Trigonometri. Jurnal Pendidikan Matematika, 2(1), 1-6.

Sriyono. (1992). Teknik Belajar Mengajar CBSA. Jakarta: Rineka Cipta.

Sudijarto. (1993). Menuju Pendidikan Nasional yang Relevan dan Bermutu. Jakarta: Balai Pustaka.

Sudjana, N. (1992). Penilaian Hasil Proses Belajar Mengajar. Bandung: PT Remaja Rosdakarya.

Sugiyono. (2016). Metode Penelitian Kuantitatif Kualitatif dan Kombinasi (Mixed Methodes). Bandung: Alfabeta.

Suprijono, A. (2013). Cooperative Learning Teori dan Aplikasi Paikem. Yogyakarta: Pustaka Pelajar.

Zaini, A., \& Marsigit. (2014). Perbandingan Keefektifan Pembelajaran Matematika dengan Pendekatan Matematika Realistik dan Konvensional ditinjau dari Kemampuan Penalaran dan Komunikasi Matematik Siswa. Jurnal Riset Pendidikan Matematika, 1(2), 152-163. https://doi.org/10.21831/jrpm.v1i2.2672 